\title{
Online Tourist Behavior of the Net Generation: An Empirical Analysis in Taiwan Based on the AISAS Model
}

\author{
Lin-Lin Xue ${ }^{1,2}$, Ching-Cheng Shen ${ }^{2, *}$, Alastair M. Morrison ${ }^{3}$ and Li-Wen Kuo ${ }^{2}$ \\ 1 College of Science and Technology, Ningbo University, Ningbo 315211, China; xuelinlin@nbu.edu.cn \\ 2 Graduate Institute of Tourism Management, National Kaohsiung University of Hospitality and Tourism, \\ Kaohsiung 812301, Taiwan; alice5504582@gmail.nkuht.edu.tw \\ 3 Department of Marketing, Events and Tourism, Business School, University of Greenwich, \\ London SE109SL, UK; a.morrison@greenwich.ac.uk \\ * Correspondence: sccheng@mail.nkuht.edu.tw
}

Citation: Xue, L.-L.; Shen, C.-C.; Morrison, A.M.; Kuo, L.-W. Online Tourist Behavior of the Net Generation: An Empirical Analysis in Taiwan Based on the AISAS Model. Sustainability 2021, 13, 2781. https:// doi.org/10.3390/su13052781

Academic Editor: Blanca Hernandez Ortega

Received: 21 January 2021

Accepted: 27 February 2021

Published: 4 March 2021

Publisher's Note: MDPI stays neutral with regard to jurisdictional claims in published maps and institutional affiliations.

Copyright: (c) 2021 by the authors. Licensee MDPI, Basel, Switzerland. This article is an open access article distributed under the terms and conditions of the Creative Commons Attribution (CC BY) license (https:/ / creativecommons.org/licenses/by/ $4.0 /)$.

\begin{abstract}
This study was intended to investigate the online behavior of Taiwan's Net Generation (born between 1977 and 1997) based on Dentsu's AISAS (Attention-Interest-Search-Action-Share) model. A conceptual framework and several hypotheses were developed and tested. A questionnaire survey was conducted in Taiwan in 2018 with 338 valid responses being received. The data were analyzed through linear regression analysis with learning and growth set as the dependent variable. Information search was the key action variable and especially during travel. Attention and interest had significant indirect influences on actions, which impacted sharing, learning, and growth. Learning and growth and action increased sharing. Post-travel sharing stimulated attention and was a catalyst for another cycle of AISAS. This research intended to fill a gap in the literature by examining the relationships among stages in the online purchase and consumption of travel products and services.
\end{abstract}

Keywords: Net Generation; learning and growth; AISAS model; Engel-Kollat-Blackwell (EKB) consumer decision model; information search before travel; information search during travel; sharing

\section{Introduction}

The development of information communication technologies (ICTs) has had significant impacts on tourism and has drawn much academic attention over the past approximately 25 years [1-4]. Online information search and booking of tourism products has become the norm. Search behavior is an important factor, which is changing enterprise business models to better cater to demand [5]. The Taiwan Network Information Center [6] stated that online booking and mobile payments are more highly accepted by the Net Generation than other age groups, indicating that real-time booking and mobile payment modes will become stronger trends in the future.

Scholarly research on online travel consumption has become significant. The rapid development of ICTs has made it even more critical to understand the impact of information on consumer behavior. Previous studies have focused on the impact of online reviews $[7,8]$ and e-word-of mouth (eWoM) [9-11] on consumer purchases, as well as factors affecting online consumption intentions [12-14]. These research studies tend to place more emphasis on information search prior to the purchase decision. However, empirical studies on information collection and implications on consumption decisions across the entire travel process are scarcer. Therefore, this research was intended to fill a gap in the literature by examining the relationships among stages in the online purchase and consumption of travel products and services. Based on the AISAS model proposed by Dentsu, the research frame was developed. LISREL was employed to test the hypotheses and influence paths. The results showed that information search was the key action variable and especially during travel. Attention and interest had significant indirect influences on actions, which 
impacted sharing, learning, and growth. Learning and growth and action increased sharing. Post-travel sharing stimulated attention and was a catalyst for another cycle of AISAS.

\section{Literature Review and Hypotheses Development}

\subsection{Consumer Buying Stages}

One of the major areas of consumer behavior theory and research has been the focus on consumer buying stages. It is recognized that people go through an ordered, sequential set of steps and decision-making when buying products and services. Several models have been proposed of buying process stages and those by Howard and Sheth in their book [15]. The Theory of Buyer Behavior, and the Engel, Kollat, and Blackwell [16] consumer decision model from their book, Consumer Behavior, are among the most popularly cited. The Howard-Sheth model identified sequential buying process stages as being need recognition, search for information (internal and external), evaluation of alternatives, purchase, postpurchase evaluation, and divestment [15]. Authors in tourism have made slight changes to this model, including adding consumption (actual travel and destination experiences) after purchase and replacing divestment with the remembering and sharing of travel experiences [17].

Engel, Kollat, and Blackwell [16] proposed the EKB consumer decision model, which includes inputs, information processing, decision-making process, decision variables, and external factors. The EKB model is similar to the Howard-Sheth model in the decisionmaking part. Only a few studies in tourism and hospitality have so far applied the EKB model [18-20]. Osei and Abenyin applied the EKB model to identify the use and influence of social media across all stages of travel decision-making for trips to Ghana in West Africa [20]. Dimitriou and AbouElgheit used EKB as a base in a conceptual paper, proposing a five-stage decision-making model for Generation $\mathrm{Z}$ travelers in the context of social media and mobile technologies [18]. Han, Zhang, and Wang (2020) also used EKB as a base in a study of online ticket reservation systems in China [19].

These models of consumer buying stage processes are widely accepted; however, it is noteworthy that most were developed in the pre-Internet era and buying behavior has significantly changed since then. Before describing these changes, the next section of the literature review considers the research on travel planning and consumption processes.

\subsection{Travel Planning and Consumption Processes}

Travel planning and consumption can be considered as a distinctive type of consumer buying. There has been a considerable volume of research on how people plan travel trips and consume the products and services of the hospitality and tourism sector. Woodside and King put forward a complex purchase consumption system for leisure travelers comprised of 19 steps in three stages: (1) thinking and planning actions prior and during travel; (2) specific decisions and actions; and (3) trip event-specific and trip-global evaluations and conations [21]. Choi et al. depicted a hierarchical and sequential structure of the travel planning process consisting of vacation sub-decisions (departure date, travel budget, length of trip, travel mode, accommodation, attractions, and activities), information sources (various websites, travel agents and tour operators, WoM, guidebooks, TV and magazines), and decision steps and stages (planning initiation, destination choice, booking and purchase, and onsite stay) [22].

The traditional view of just three stages (pre-, during-, and post-travel) has been challenged both by academic researchers $[18,21,22]$ and practitioners $[23,24]$. Dimitriou and AbouElgheit outlined five steps in the decision-making process: (1) inspiration; (2) need for social recognition; (3) planning, search, and evaluation; (4) booking; and (5) post-booking evaluations [18]. From a practitioner viewpoint, Team Tourism Consulting identified four stages when travelers use online information-dreaming, enthusing, and informing; planning, selecting, and booking; visiting and enjoying; and repeating, recommending, and recollecting [24]. The Dentsu approach is discussed later in reviewing the AISAS model [23]. 
A consensus has, therefore, developed that there are more than three stages in the decision process since the Internet took hold of markets. A cycle of travel behavior can now be divided into the triggering of intention, seeking travel information, booking products, using products during travel, and sharing personal experiences after trips. People may develop travel intentions because of friends sharing or advertising. Before departure, they search for information and products on travel platforms and make purchases. During travel, they also search for information on itineraries, attractions and activities, transportation, and restaurants through online platforms to make trip experiences more enjoyable. After returning home, they share experiences with friends or netizens [25]. These functions are all greatly facilitated by online travel platforms of various types and that is the next topic in this literature review.

\subsection{Online Travel Booking and Sales}

Online information and travel platforms have revolutionized how people plan, book, and enjoy travel experiences. Due to ICT advancement and the popularity of the Internet, consumer purchase behaviors have changed. Compared with the traditional channels of tourism distribution, the advantages of the Internet lie in information richness, and convenience of booking and purchasing [3,26,27]. Tourists are now more dependent on the Internet for information search, planning, and purchasing travel products and services $[1,28,29]$. In addition, this is making independent travel options more popular. According to the Taiwan Ministry of Transportation and Communications, most Taiwanese tourists $(90.1 \%)$ plan their own travel itineraries and travel by themselves $(87.9 \%)$ rather than in organized tour groups [30]. Independent travelers make use of social media across the entire travel process $[20,31]$. It is now very common for travelers to search, organize, and share travel experiences through various online tools such as blogs, social media sharing sites, chat, and social knowledge sharing sites [28]. These platforms provide individual control and greater autonomy. Using them, allows travelers to move around at their own pace, planning individualized itineraries, and have more in-depth experiences of life at destinations thereby better appreciating local cultures and lifestyles, while promoting more self-learning and personal growth. These benefits created through autonomous behavior can result in higher levels of company and destination brand belief and post-trip satisfaction and loyalty [28,32].

In addition, online travel agencies (OTAs) and other online tourism suppliers have the (big) data to be sensitive to changes in customer needs and market trends, and thus can update and develop new products to suit the market [33,34]. When a company is able to present its new products to the market faster than its competitors, it can increase sales volume and market share, and achieve greater profitability, productivity, and effectiveness $[35,36]$. With rapid socioeconomic changes and digital development, innovative and precise promotions help change customer purchasing behaviors and improve an organization's competitive advantage [37,38]. The widespread use of mobile communications and social media has completely changed the way consumers live and how organizations conduct marketing [39-41]. One of these changes has been the emergence of content marketing and co-creation.

\subsection{Content Marketing and Co-Creation}

While traditional marketing and advertising is still present, digital marketing and advertising is growing much more rapidly. In the digital marketing sphere, content marketing is a way for customers to take the initiative in looking for product information and also represents an opportunity for hospitality and travel marketers to curate meaningful materials for them [42,43]. The Content Marketing Institute (CMI) (2014) defined content marketing to be "a strategic marketing approach focused on creating and distributing valuable, relevant, and consistent content to attract and retain a clearly-defined audience-and ultimately, to drive profitable customer action". Content marketing engages customers who resonate with materials in various forms and conveys the information they want to know. 
Having obtained the needed information, they gradually develop a sense of trust in brands because the materials provided solve problems. Compared with traditional advertising, it is easier for companies and destinations to get closer to customers who are interested in or have needs for their products and services. In his book Marketing 4.0, Kotler proposed the concept of the marketing funnel in which the content marketing process is summarized as awareness, research, and thinking [44]. Awareness is making customers pay attention to products and services. Research is the behavior by customers to become more familiar with product contents by looking for information once they notice potential products that satisfy their needs. Consideration is the product comparison made by customers to ensure that they make the best purchase decisions.

Co-creation is a concept allied with content marketing and involves the co-production of information, materials, and experiences by customers and hospitality and travel marketers $[45,46]$. Co-creation covers a broad spectrum including value co-creation within the context of information technology. Cabiddu, Lui, and Piccoli demonstrated the presence of online co-creation with the case of the Open Voucher scheme in Sardinia, Italy. In the context of this research, the sharing of experiences in text, photos, and videos, either solicited or unsolicited, can be considered as co-creation [47]. It demonstrates a higher level of engagement with travelers who are willing to share online, and the Net Generation may be one of these groups.

\subsection{Net Generation}

The Net Generation, also known as the N-generation and the digital natives, are people aged between approximately 23 and 43 in 2020 [48,49]. They were the first group as children to be brought up surrounded by ICTs including the Internet and the first cohort to enter universities and colleges in the early years of Web 1.0. It is widely assumed that these people are very savvy and skilled about using various ICTs and particularly the Internet, and that was part of the reason for this research's focus on them. However, empirical research has indicated that the Net Generation is not homogenous in its use and liking of ICTs [50,51]; in researching first-year university students in the UK, it concluded that the Net Generation was not "homogenous in its use and appreciation of new technologies". Hargittai discovered, in a survey of first-year students in a US university, that those with a higher socioeconomic status among the Net Generation were making more informed use of the Web [50]. Therefore, it is important to develop a more in-depth understanding of how the Net Generation searches for and uses online travel information. In so doing, it is helpful to analyze online usage from the perspective of tried and tested models of purchasing habits.

\subsection{The AIDA Model and Hierarchy of Effects}

Apart from the models put forward by consumer behavior and tourism researchers, approaches have also been proposed by marketing and advertising practitioners. These models tended to be process-oriented and outlined the consumer stages and how marketers should attempt to appeal the most effectively in each stage. One of the first of these was the AIDA (attention, interest, desire, action) approach, also known as a hierarchy of effects model. This means that consumers progress in their learning and decision-making as they acquire information from a starting point of unawareness to the pinnacle of a hierarchy represented by taking actions through purchasing. AIDA was the first such model and is attributed to Lewis around 1900 [52,53]. While AIDA has been widely applied in marketing, its use in academic research studies and particularly related to digital media is extremely limited [54].

\subsection{The AIDMA and AISAS Models}

AIDA was the first hierarchy of effects model in marketing. It was followed by AIDMA (Attention-Interest-Desire-Memory-Action) proposed by Hall, which was the predecessor of the AISAS (Attention-Interest-Search-Action-Share) model [55]. Due to 
the growing impact of Internet technology on consumer behavior, Dentsu observed that the way consumers receive marketing information was being influenced. They were no longer just passively receiving information; now they were actively seeking it. Dentsu proposed the AISAS model to better characterize consumer behavior in the Internet era [23]. A Japanese advertising company noticed that the mode for consumers to get marketing information had changed from just receiving to actively looking for materials. The new AISAS model was proposed and considered to be more suitable than the traditional AIDA or AIDMA models for explaining consumption behavior in the Internet era. Some research studies have been done based on the AISAS model [56-61]. However, it has been used in very few studies related to tourism and hospitality $[62,63]$ and investigations of online travel consumption behavior are also scarce.

Chen \& Huang integrated S-O-R (Stimulus-Organism-Response) into AISAS to reflect the role of eWoM [64]. The major difference between AISAS and AIDMA lies in search and sharing. With the Internet, consumers readily search for information about the products or services they want and are more willing to share online purchasing experiences. The conceptual difference between AISAS and AIDMA lies in the change in advertising, which has switched from consumer persuasion to information interactions. This is caused by communication environment changes; the rise and stature of the Internet make it an inseparable part of consumers' daily lives. All necessary information is available there; they are no longer limited to television, broadcasting, newspapers, and magazines [27]. Moreover, consumers have transformed from information receivers to active information seekers and even interact with those who publish information [65]. The popularity of mobile devices is one of the catalysts for this transformation. Mobile devices have changed lifestyles and have become a new communication media channel, which enables consumers to choose the information they want to receive anytime and anywhere. Consequently, advertising can also work by interacting with consumers, not through informing and persuasion [66]. When consumers see advertisements for a brand or company via television, newspapers, and magazines, they become interested in the products and search for more relevant information. The traditional way of advertising involves impressing consumers with ads to promote purchase. However, it is more convenient and easier for consumers to search for information on the Internet and they can find more detailed product and service information by themselves. The behavior of searching for products and services often accidentally leads to the possibility of other products being purchased. Therefore, compared with traditional forms of marketing, the active search for information is more effective in promoting actual purchases. Information search has become an important part of consumer behavior as it combines information with user experiences and enables consumers to use the Internet to easily communicate with each other. This is often a determinant of the WoM for a product or service [67].

Due to the rapid flow of information, not only do brands communicate with consumers but consumers themselves have become part of advertising. When describing consumer decision-making behavior, Dentsu replaced "desire" and "memory" in the AIDMA model with "search" and "share" because they were more applicable to the Internet generations. In the AISAS model, a product or an advertisement attracts attention and the information is used to maintain consumer interest in the product. However, the difference lies in the driving force of the Internet, which enables consumers to adapt from passive recipients into active seekers of information. When their search is completed, consumers take "action" to make purchases. Having used the products or services, they begin to "share" their first-hand user experiences with others in the form of eWoM. The emergence of eWoM is not only a source of information for potential consumers but also starts the next round of attention and search. Compared with the AIDMA model, AISAS emphasizes the process of search and sharing, which fully embodies the media usage habits and consumer behaviors of the Internet generations. In addition, the search and sharing behaviors are effective in increasing purchase frequency [68]. Abdurrahim, Najib, and Djohar explored the influence of destination marketing organization (DMO) social media on tourist choices 
of destinations based on the AISAS model [62]. Their research analyzed whether DMO social media promotions attracted the attention and interest of tourists to pique their desire to search for relevant information about destinations. They also investigated the impact of information seeking on tourist decision-making and whether visiting destinations influenced the sharing of experiences.

Consumers now increasingly look for their ideal products and services via online search. The information they find not only includes those published by companies and destinations about certain brands, but also feedback and comments, both positive and negative, uploaded by consumers who have already used them. The persuasiveness of reviews and comments is almost equal to or more influential to the advertising of companies and destinations [31,69]. Having made purchases, consumers share their own experiences and suggestions with others, which triggers the next cycle of search [70].

When consumers experience a series of psychological changes caused by external incentives and internal needs, their attention is drawn to certain products or services. This may generate interest, search for relevant information, and decisions on whether to purchase products or services [71] and then make the actual purchase. Shim, Eastlick, and Lotz explored the relationship between search intent and purchase intentions [72]. This revealed that the intention to search for product attributes online was a determinant of purchase intention. Searching for information and booking products are two stages before travel [73]. Lee, Qu, and Kim studied the online shopping behavior of travelers, expanded the theory of reasoned action (TRA) with search intent and purchase intention, and emphasized the importance of information search as a prerequisite for travel decisionmaking [74]. Chen and Huang established the model of Online Word-of-Mouth Marketing (OWoM) based on AISAS, which was represented as attention $\rightarrow$ interest $\rightarrow$ search $\rightarrow$ action $\rightarrow$ share $\rightarrow$ OWoM [64]. Lin and Chen expanded the AISAS model by adding sociality, exploring the effect of an AR (augmented reality) wedding invitation app [75]. The results demonstrated positive relationships between attention and interest, interest and search, search and sociality, sociality and behavior, and behavior and sharing. Hendriyani et al. used the AISAS model to analyze the online consumer behavior of Twitter users and found that there were positive relationships between attention and interest, interest and search, and search and behavior [56]. Cheah, Ting, Cham, and Memon applied AISAS to compare the effect of celebrity-endorsed advertising and selfie promotion and found that the AISAS model with selfie promotion produced better predictive ability while attention had a positive impact on interest, interest on search, search on behavior, and behavior on sharing [76]. Therefore, the following hypotheses were proposed:

Hypotheses 1 (H1). Attention has a positive effect on interest.

Hypotheses 2a (H2a). Interest has a positive effect on search before travel.

Hypotheses $\mathbf{2 b}(\mathbf{H} 2 \mathbf{b})$. Interest has a positive effect on search during travel.

Hypotheses 3a (H3a). Search before travel has a positive impact on action.

Hypotheses $\mathbf{3 b} \mathbf{b} \mathbf{H} \mathbf{3 b})$. Search during travel has a positive effect on action.

Hypotheses 4 (H4). Action has a positive impact on post-travel sharing.

There are also nonlinear effects in the AISAS model in addition to the linear ones. Hendriyani et al. (2013) found that attention had significant positive effects on search, attention on action, attention on sharing, interest on search, interest on sharing, and search on sharing [56]. Cheah et al. found that attention had a significant positive effect on search, interest on behavior, and search on sharing [76]. Abdurrahim, Najib, and Djohar determined that: (1) social media had a positive impact on attention, interest, and search; (2) attention had a positive effect on sharing; (3) action had a positive impact on sharing; and (4) interest had no significant impact on action [62]. Kono proposed that sharing one's own experience or suggestions with others after using certain products triggers the information 
search of other people, which is the beginning of another round of the tourism cycle [70]. Therefore, the following hypotheses were proposed:

Hypotheses 5 (H5). Attention has a positive effect on search before travel.

Hypotheses 6 (H6). Attention has a positive effect on search during travel.

Hypotheses 7 (H7). Interest has a positive effect on action.

Hypotheses 8a (H8a). Search before travel has a positive impact on sharing after travel.

Hypotheses $\mathbf{8 b} \mathbf{( H 8 b ) . ~ S e a r c h ~ d u r i n g ~ t r a v e l ~ h a s ~ a ~ p o s i t i v e ~ i m p a c t ~ o n ~ s h a r i n g ~ a f t e r ~ t r a v e l . ~}$

Hypotheses 9 (H9). Post-travel sharing has a positive effect on attention.

Independent travelers may develop deeper understandings through their travel experiences, thus achieving self-affirmation and growth. They have a high degree of autonomy and flexibility in travel planning in terms of transportation, accommodation, and recreational activities [77,78]. Independent travel is more autonomous and flexible [79] and authentic experiences are considered to be the charm of travel [80].

Loker-Murphy explored the motivations of backpackers when traveling in Australia, which were divided into four types: escape/relaxation, society/stimulation, selfdevelopment, and pursuing a sense of achievement [81]. Elsrud (2001) suggested that backpackers love traveling freely and start in-depth traveling along their planned routes when they can, hoping to deeply explore local areas through their own perspectives and realizing their own desires and needs [82,83]. This implies that independent travelers can achieve learning and growth goals in the process of traveling. Loker-Murphy and Pearce discovered that backpackers prioritize getting to know others, independent organization, flexible itineraries, and long travel times [84]. Murphy emphasized the pursuit of pleasant travel experiences and the importance of interpersonal interaction with other tourists by sharing their new experiences [85]. Moreover, life growth and change brought about by traveling are also considered as characteristics of independent travelers [80]. Chen found that for the The Net Generation who seek innovation, change, and customization, travel platforms provide them with great autonomy where they can fully control travel pace, plan itineraries, experience local life, and understand local culture more deeply, and even learn and grow on journeys [32]. Therefore, the following hypotheses were proposed:

Hypotheses 10 (H10). Learning and growth have a positive impact on post-travel sharing.

Hypotheses 11 (H11). Search before travel has a positive impact on learning and growth.

Hypotheses 12 (H12). Search during travel has a positive effect on learning and growth.

Hypotheses 13 (H13). Action exerts a positive effect on learning and growth.

This research explored the online travel consumption behavior of the Net Generation based on the AISAS model along with the introduction of the variable of learning and growth from the perspective of independent travel. The results are thought to contribute to theory and practice. They potentially enrich marketing theories related to online business by integrating the AISAS model with information search behaviors across the entire trip process. From a practical viewpoint, the findings identify key factors influencing the purchasing and sharing behavior after travel which in turn stimulates attention and leads to a new cycle of the AISAS model. This should be valuable for companies and destinations in adopting appropriate marketing strategies and delivering needed information, which enhances customer engagement and builds loyalty. The conceptual research model and hypotheses are shown in Figure 1. 


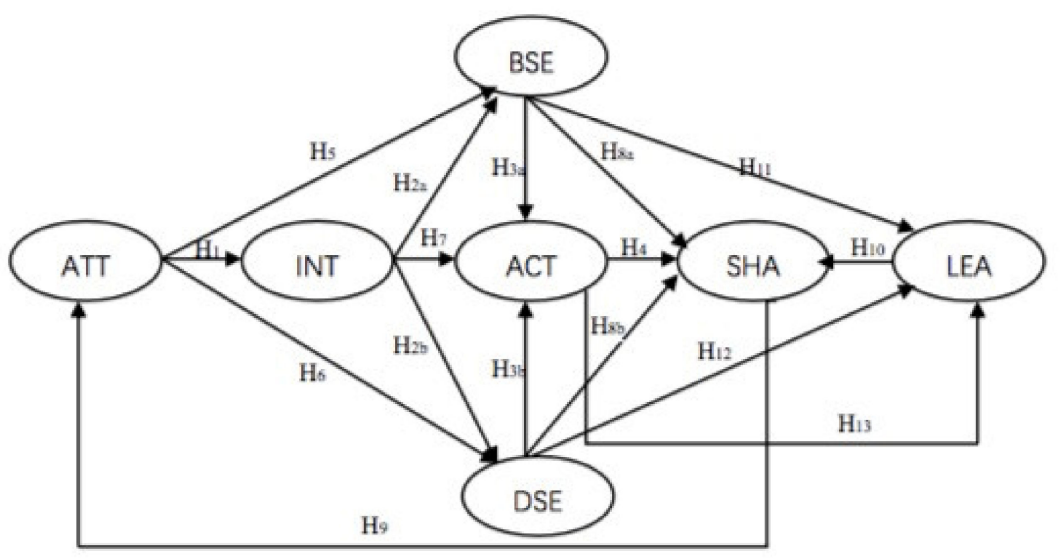

Figure 1. Conceptual research model.

\section{Methodology}

Questionnaire Design and Sample

The consumer behavior model of online travel platforms was established mainly by referring to EKB, AISAS, and the travel trip cycle with seven variables (attention-ATT, interest-INT, search before travel—BSE, search during travel—DSE, action-ACT, posttravel sharing-SHA, and learning and growth-LEA). The questionnaire used five-point Likert scales for item measurement; five for "strongly agree" and one for "strongly disagree." The seven variables were measured through a combined total of 21 items (Table 1). The items were drawn from those proposed by Engel, Kollat, and Blackwell [16]. To ensure the reliability of measurement, SPSS 21.0 was employed for item analysis. The criteria for retention were that items must pass a test of the CR value reaching a significant level $(p<0.05)$ and a correlation between the item and the total items above 0.5 (Table 1). All the $\mathrm{CR}$ values of the 21 items were significant and were retained.

Table 1. Questionnaire item analysis.

\begin{tabular}{|c|c|c|c|c|c|c|}
\hline Factors & Item Codes & Items & Mean & S.D. & CR & $\begin{array}{l}\text { Item-to-Total } \\
\text { Correlation }\end{array}$ \\
\hline \multirow{2}{*}{ Attention } & ATT 1 & Triggering my motivation to travel & 3.80 & 0.773 & $11.378^{* * *}$ & 0.539 \\
\hline & ATT 2 & Hoping to experience the local area & 4.04 & 0.785 & $13.500^{* * *}$ & 0.642 \\
\hline \multirow{2}{*}{ Interest } & INT 1 & $\begin{array}{l}\text { Allowing me to plan a customized itinerary } \\
\text { for myself }\end{array}$ & 4.11 & 0.754 & $8.013^{* * *}$ & 0.500 \\
\hline & INT 2 & $\begin{array}{l}\text { Offering me the possibility of traveling } \\
\text { according to my own interests }\end{array}$ & 4.32 & 0.656 & $12.294^{* * *}$ & 0.614 \\
\hline \multirow{3}{*}{$\begin{array}{l}\text { Search before } \\
\text { travel }\end{array}$} & BSE 1 & $\begin{array}{l}\text { Providing me access to retrieve travel } \\
\text { information/comments }\end{array}$ & 4.38 & 0.634 & $9.997^{* * *}$ & 0.513 \\
\hline & BSE 2 & Providing me various travel information & 4.30 & 0.703 & $15.864^{* * *}$ & 0.671 \\
\hline & BSE 3 & $\begin{array}{c}\text { Providing me access to compare the prices } \\
\text { of tourism products }\end{array}$ & 4.26 & 0.674 & $14.900 * * *$ & 0.630 \\
\hline \multirow{3}{*}{$\begin{array}{l}\text { Search during } \\
\text { travel }\end{array}$} & DSE 1 & $\begin{array}{l}\text { I use travel platforms to find instant } \\
\text { messages about traveling during my } \\
\text { journey }\end{array}$ & 3.94 & 0.815 & $10.938^{* * *}$ & 0.500 \\
\hline & DSE 2 & $\begin{array}{l}\text { I use travel platforms to search for food and } \\
\text { restaurants nearby during my journey }\end{array}$ & 4.18 & 0.791 & $12.788^{* * *}$ & 0.567 \\
\hline & DSE 3 & $\begin{array}{c}\text { I use it to search for nearby scenic spots } \\
\text { during my journey }\end{array}$ & 4.22 & 0.744 & $11.493 * * *$ & 0.566 \\
\hline
\end{tabular}


Table 1. Cont.

\begin{tabular}{|c|c|c|c|c|c|c|}
\hline Factors & Item Codes & Items & Mean & S.D. & CR & $\begin{array}{l}\text { Item-to-Total } \\
\text { Correlation }\end{array}$ \\
\hline \multirow{5}{*}{ Action } & ACT 1 & $\begin{array}{c}\text { Allows me to book travel products and } \\
\text { services }\end{array}$ & 4.26 & 0.679 & $14.706^{* * *}$ & 0.623 \\
\hline & ACT 2 & $\begin{array}{l}\text { I use digital maps to navigate during my } \\
\text { journey }\end{array}$ & 4.48 & 0.685 & $10.108^{* * *}$ & 0.508 \\
\hline & ACT 3 & $\begin{array}{c}\text { I use the function of "registering" during } \\
\text { travel }\end{array}$ & 3.67 & 1.054 & $9.266^{* * *}$ & 0.500 \\
\hline & ACT 4 & I record the good memories of my journey & 3.95 & 0.884 & $18.224^{* * *}$ & 0.694 \\
\hline & ACT 5 & $\begin{array}{l}\text { Increasing the interaction between the } \\
\text { community and me }\end{array}$ & 3.84 & 0.883 & $13.855^{* * *}$ & 0.601 \\
\hline \multirow{3}{*}{$\begin{array}{l}\text { Sharing after } \\
\text { travel }\end{array}$} & SHA 1 & $\begin{array}{l}\text { Travel platforms make it convenient for me } \\
\text { to leave comments on tourism products }\end{array}$ & 3.89 & 0.799 & $12.555^{* * *}$ & 0.564 \\
\hline & SHA 2 & $\begin{array}{l}\text { Travel platforms enable me to record and } \\
\text { share my own tourism experiences }\end{array}$ & 3.87 & 0.858 & $21.157^{* * *}$ & 0.716 \\
\hline & SHA 3 & $\begin{array}{l}\text { Travel platforms provide a place for me to } \\
\text { record/share my travel experiences at the } \\
\text { end of my journey }\end{array}$ & 3.94 & 0.857 & $16.862^{* * *}$ & 0.681 \\
\hline \multirow{3}{*}{$\begin{array}{l}\text { Learning and } \\
\text { growth }\end{array}$} & LEA 1 & Understanding local culture deeply & 3.95 & 0.793 & $13.316^{* * *}$ & 0.626 \\
\hline & LEA 2 & $\begin{array}{l}\text { Learning how to overcome difficulties } \\
\text { encountered during travel }\end{array}$ & 4.08 & 0.762 & $14.891^{* * *}$ & 0.591 \\
\hline & LEA 3 & $\begin{array}{l}\text { Increasing tourism knowledge and } \\
\text { achieving growth }\end{array}$ & 4.17 & 0.708 & $14.242^{* * *}$ & 0.631 \\
\hline
\end{tabular}

$$
\text { Note: }{ }^{* * *} p<0.001 \text {. }
$$

The questionnaire survey was performed with convenience sampling of the Taiwanese Net Generation. The questionnaire was distributed between 7 and 31 March 2018, for a total of 25 days, through social media platforms including Facebook and Instagram. Invalid questionnaires were removed. A total of 405 questionnaires were distributed, of which $338(83.5 \%)$ were valid.

\section{Research Results}

\subsection{Descriptive Statistics}

The demographic characteristics of respondents are shown in Table 2. The majority $(61.5 \%)$ were aged between 21 and 25 , while $27.8 \%$ were from 26 to 35 . Some $62.7 \%$ were women while $37.3 \%$ were men. The majority $(78.7 \%)$ had finished college. Most $(29.6 \%)$ were students or worked in the tertiary sector (25.1\%). Northern Taiwan had $46.4 \%$ while $36.1 \%$ lived in Southern Taiwan.

Table 2. Descriptive analysis of AISAS and learning and growth.

\begin{tabular}{ccccc}
\hline Characteristics & Items & Sample & \% \\
\hline \multirow{3}{*}{ Age } & $21-25$ & 208 & 61.5 \\
\cline { 2 - 4 } & $26-30$ & 47 & 13.9 \\
\cline { 2 - 4 } & $31-35$ & 47 & 13.9 \\
\cline { 2 - 4 } & $36-41$ & 36 & 10.7 \\
\cline { 2 - 4 } Gender & Male & 126 & 37.3 \\
\cline { 2 - 4 } & Female & 212 & 62.7 \\
\hline
\end{tabular}


Table 2. Cont.

\begin{tabular}{cccc}
\hline Characteristics & Items & Sample & \% \\
\hline \multirow{3}{*}{ Place of residence } & North Taiwan & 157 & 46.4 \\
\cline { 2 - 4 } & Central Taiwan & 52 & 15.4 \\
\cline { 2 - 4 } & South Taiwan & 122 & 36.1 \\
\cline { 2 - 4 } Education & Others & 7 & 2.1 \\
\cline { 2 - 4 } & Senior high school & 30 & 8.9 \\
\cline { 2 - 4 } & University/college & 266 & 78.7 \\
\cline { 2 - 4 } & Master and above & 42 & 12.4 \\
\cline { 2 - 4 } Occupation & Students & 100 & 29.6 \\
\cline { 2 - 4 } & Industry & 29 & 4.7 \\
\cline { 2 - 4 } & Business & 5.6 \\
\cline { 2 - 4 } & Servicemen civil servants and teachers & 16 & 17.5 \\
\cline { 2 - 4 } & Tertiary industry & 49 & 25.1 \\
\cline { 2 - 4 } & Others & 14.5 \\
\cline { 2 - 4 } & &
\end{tabular}

\subsection{Reliability and Validity Analysis}

SPSS 21.0 statistical software was used to test the reliability and validity of the questionnaire items. Cronbach's alpha and composite reliability (CR) served as the indicators of reliability. Table 3 shows that the Cronbach's alpha values of each dimension were between 0.564 and 0.830 and CR values from 0.821 and 0.900 , which indicated that item reliability was sufficient. The average variation extracted (AVE) of all factors were from 0.553 and 0.723 , and greater than 0.5 , indicating that there was good convergent validity. The means of each factor are shown in Table 3 wherein the mean of search before travel is the highest, followed by interest and search during travel. Table 4 indicates that the square roots of the AVEs were greater than the correlation coefficients of the variables, indicating that all variables met the test for discriminant validity.

Table 3. Reliability and validity analysis of AISAS.

\begin{tabular}{cccccc}
\hline Factors & Mean & SD & $\begin{array}{c}\text { Cronbach's } \\
\text { Alpha }\end{array}$ & CR & AVE \\
\hline ATT & 3.9201 & 0.6499 & 0.564 & 0.821 & 0.697 \\
\hline INT & 4.2145 & 0.5922 & 0.575 & 0.826 & 0.704 \\
\hline BSE & 4.3107 & 0.5607 & 0.785 & 0.875 & 0.700 \\
\hline DSE & 4.1144 & 0.6446 & 0.761 & 0.876 & 0.687 \\
\hline ACT & 4.0420 & 0.5881 & 0.729 & 0.828 & 0.553 \\
\hline SHA & 3.8994 & 0.7124 & 0.807 & 0.900 & 0.695 \\
\hline LEA & 4.0690 & 0.6403 & 0.805 & 0.866 & 0.723 \\
\hline
\end{tabular}

Table 4. Discriminant validity of AISAS and learning and growth.

\begin{tabular}{cccccccc}
\hline & ATT & INT & BSE & DSE & ACT & SHA & LEA \\
\hline ATT & 0.835 & & & & & \\
\hline INT & 0.617 & 0.839 & & & & \\
\hline BSE & 0.568 & 0.673 & 0.837 & & \\
\hline DSE & 0.462 & 0.403 & 0.519 & 0.829 & & \\
\hline
\end{tabular}


Table 4. Cont.

\begin{tabular}{cccccccc}
\hline & ATT & INT & BSE & DSE & ACT & SHA & LEA \\
\hline ACT & 0.548 & 0.464 & 0.587 & 0.565 & 0.744 & & \\
\hline SHA & 0.558 & 0.437 & 0.496 & 0.495 & 0.683 & 0.833 & \\
\hline LEA & 0.638 & 0.632 & 0.535 & 0.478 & 0.585 & 0.588 & 0.850 \\
\hline
\end{tabular}

\subsection{Hypotheses Tests}

Regression analysis was adopted to explore the relationships between variables. The path diagram is shown in Figure 2 and the relationships between variables are summarized in Table 5. Twelve of the 15 hypotheses were supported showing significant positive effects between pairs of variables; while three hypotheses did not receive support.

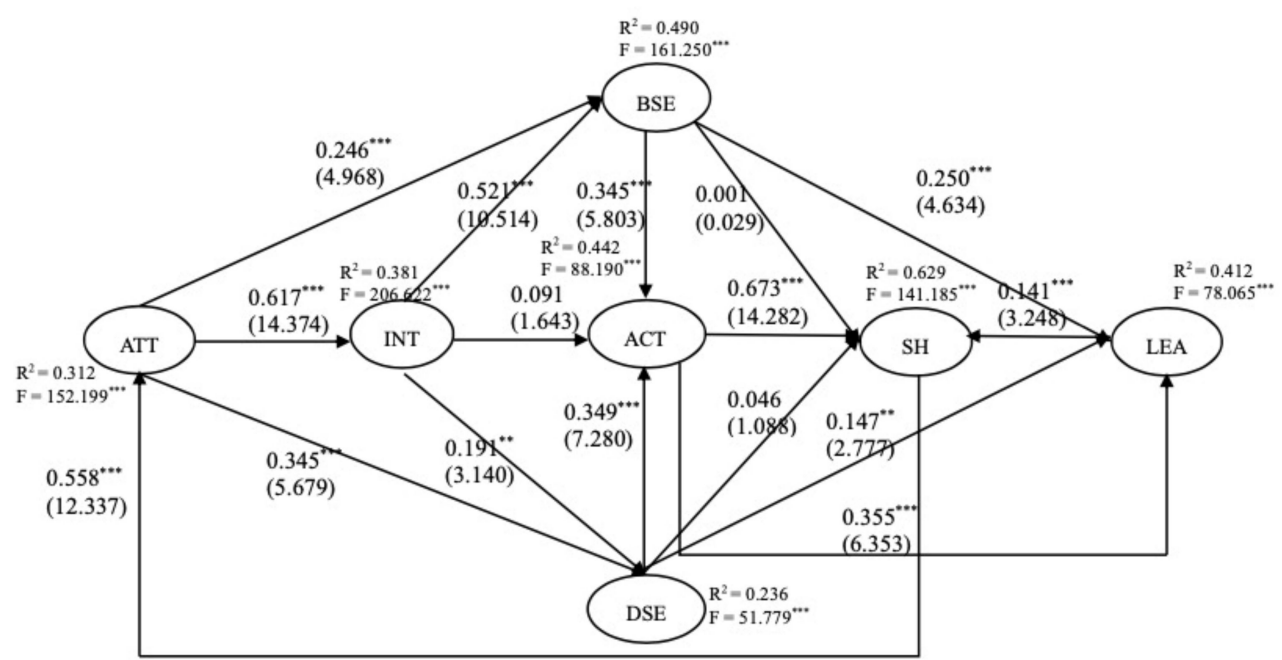

Figure 2. Path diagram of relationships among variables. Note: ${ }^{* *} p<0.001,{ }^{* *} p<0.01,{ }^{*} p<0.05$.

Table 5. Hypotheses tests.

\begin{tabular}{cccccc}
\hline Hypothesis & Beta Coefficient & $\boldsymbol{t}$ Value & $\boldsymbol{p}$ & Testing & Result \\
\hline H1 & 0.617 & 14.374 & 0.000 & $p<0.05$ & Supported \\
\hline H2a & 0.521 & 10.514 & 0.000 & $p<0.05$ & Supported \\
\hline H2b & 0.191 & 3.140 & 0.002 & $p<0.05$ & Supported \\
\hline H3a & 0.345 & 5.803 & 0.000 & $p<0.05$ & Supported \\
\hline H3b & 0.349 & 7.280 & 0.000 & $p<0.05$ & Supported \\
\hline H4 & 0.673 & 14.282 & 0.000 & $p<0.05$ & Supported \\
\hline H5 & 0.246 & 4.968 & 0.000 & $p<0.05$ & Supported \\
\hline H6 & 0.345 & 5.679 & 0.000 & $p<0.05$ & Supported \\
\hline H7 & 0.091 & 1.643 & 0.101 & $p>0.05$ & Not supported \\
\hline H8a & 0.01 & 0.029 & 0.977 & $p>0.05$ & Not supported \\
\hline H8b & 0.046 & 1.088 & 0.277 & $p>0.05$ & Not supported \\
\hline H9 & 0.558 & 12.337 & 0.000 & $p<0.05$ & Supported \\
\hline H10 & 0.141 & 3.248 & 0.001 & $p<0.05$ & Supported \\
\hline H11 & 0.250 & 4.634 & 0.000 & $p<0.05$ & Supported \\
\hline H12 & 0.147 & 2.777 & 0.006 & $p<0.05$ & Supported \\
\hline H13 & 0.355 & 6.353 & 0.000 & $p<0.05$ & Supported \\
\hline
\end{tabular}


- $\quad$ Attention (ATT) and interest $(\mathrm{INT})=0.617, t$-value $=14.374 ; \mathrm{H} 1$ supported

- Interest (INT) and search before travel (BSE) $=0.521, t$-value $=10.514 ; \mathrm{H} 2 \mathrm{a}$ supported

- Interest (INT) and search after travel (DSE) $=0.191, t$-value $=3.140 ; \mathrm{H} 2 \mathrm{~b}$ supported.

- $\quad$ Search before travel (BSE) and action (ACT) $=0.345, t$-value $=5.803 ; \mathrm{H} 3$ a supported.

- $\quad$ Search after travel (DSE) and action (ACT) $=0.349, t$-value $=7.280 ; \mathrm{H} 3 \mathrm{~b}$ supported.

- Action (ACT) and post-travel sharing (SHA) $=0.673, t$-value $=14.282 ; \mathrm{H} 4$ supported

- Attention (ATT) and search before travel $(\mathrm{BSE})=0.246, t$-value $=4.968 ; \mathrm{H} 5$ supported

- Attention (ATT) and search after travel $(\mathrm{DSE})=0.345, t$-value $=5.679 ; \mathrm{H} 6$ supported.

- Interest (INT) and action (ACT) $=0.091, t$-value $=1.643$; no significant positive effect; H7 not supported.

- Search before travel (BSE) and post-travel sharing (SHA) $=0.001, t$-value $=0.029$; no significant positive effect; H8a not supported.

- Search after travel (DSE) and post-travel sharing (SHA) $=0.046, t$-value $=1.088$; no significant positive effect; H8b not supported.

- $\quad$ Post-travel sharing (SHA) and attention (ATT) $=0.558, t$-value $=12.337 ; \mathrm{H} 9$ supported .

- $\quad$ Learning and growth (LEA) and post-travel sharing (SHA) $=0.141, t$-value $=3.248$; H10 supported.

- $\quad$ Search before travel (BSE) and learning and growth $(\mathrm{LEA})=0.250, t$-value $=4.634$; H11 supported.

- $\quad$ Search after travel (DSE) and learning and growth $($ LEA) $=0.141, t$-value $=2.777$; H12 supported.

- Action (ACT) and learning and growth $(\mathrm{LEA})=0.355, t$-value $=6.353 ; \mathrm{H} 13$ supported

\subsection{Impact Path and Effect Analysis of Action and Sharing}

The effects of the AISAS stages on action and sharing are shown in Table 6. The factor that affected action most was attention, followed by search during travel and search after travel. The most important factors that influenced post-travel sharing were action, attention, search during travel, and search before travel, respectively. The added effects of search before travel and search during travel on action reached as high as 0.69 . The added effects of search before and during travel on post-travel sharing was as high as 0.52 , indicating that search had a great influence on tourism decision-making and post-travel sharing.

Table 6. Factors affecting action and sharing.

\begin{tabular}{|c|c|c|c|}
\hline & lence Path & Influence Effect & Overall Effect \\
\hline \multirow{4}{*}{$\mathrm{ATT} \rightarrow \mathrm{ACT}$} & $\mathrm{ATT} \rightarrow \mathrm{BSE} \rightarrow \mathrm{ACT}$ & 0.08487 & \multirow{4}{*}{0.35731} \\
\hline & $\mathrm{ATT} \rightarrow \mathrm{INT} \rightarrow \mathrm{BSE} \rightarrow \mathrm{ACT}$ & 0.11090 & \\
\hline & $\mathrm{ATT} \rightarrow \mathrm{INT} \rightarrow \mathrm{DSE} \rightarrow \mathrm{ACT}$ & 0.04113 & \\
\hline & $\mathrm{ATT} \rightarrow \mathrm{DSE} \rightarrow \mathrm{ACT}$ & 0.12041 & \\
\hline \multirow{2}{*}{$\mathrm{INT} \rightarrow \mathrm{ACT}$} & $\mathrm{INT} \rightarrow \mathrm{BSE} \rightarrow \mathrm{ACT}$ & 0.17945 & \multirow{2}{*}{0.24611} \\
\hline & $\mathrm{INT} \rightarrow \mathrm{DSE} \rightarrow \mathrm{ACT}$ & 0.06666 & \\
\hline $\mathrm{BSE} \rightarrow \mathrm{ACT}$ & $\mathrm{BSE} \rightarrow \mathrm{ACT}$ & 0.345 & 0.345 \\
\hline $\mathrm{DSE} \rightarrow \mathrm{ACT}$ & $\mathrm{DSE} \rightarrow \mathrm{ACT}$ & 0.349 & 0.349 \\
\hline \multirow{8}{*}{$\mathrm{ATT} \rightarrow \mathrm{SHA}$} & $\mathrm{ATT} \rightarrow \mathrm{BSE} \rightarrow \mathrm{ACT} \rightarrow \mathrm{SHA}$ & 0.05712 & \multirow{8}{*}{0.28792} \\
\hline & $\mathrm{ATT} \rightarrow \mathrm{INT} \rightarrow \mathrm{BSE} \rightarrow \mathrm{ACT} \rightarrow \mathrm{SHA}$ & 0.07464 & \\
\hline & $\mathrm{ATT} \rightarrow \mathrm{INT} \rightarrow \mathrm{DSE} \rightarrow \mathrm{ACT} \rightarrow \mathrm{SHA}$ & 0.02768 & \\
\hline & $\mathrm{ATT} \rightarrow \mathrm{DSE} \rightarrow \mathrm{ACT} \rightarrow \mathrm{SHA}$ & 0.08104 & \\
\hline & $\mathrm{ATT} \rightarrow \mathrm{BSE} \rightarrow \mathrm{LEA} \rightarrow \mathrm{SHA}$ & 0.00867 & \\
\hline & $\mathrm{ATT} \rightarrow \mathrm{INT} \rightarrow \mathrm{BSE} \rightarrow \mathrm{LEA} \rightarrow \mathrm{SHA}$ & 0.01133 & \\
\hline & $\mathrm{ATT} \rightarrow \mathrm{INT} \rightarrow \mathrm{DSE} \rightarrow \mathrm{LEA} \rightarrow \mathrm{SHA}$ & 0.00244 & \\
\hline & $\mathrm{ATT} \rightarrow \mathrm{DSE} \rightarrow \mathrm{LEA} \rightarrow \mathrm{SHA}$ & 0.00715 & \\
\hline
\end{tabular}


Table 6. Cont.

\begin{tabular}{|c|c|c|c|}
\hline & ce Path & Influence Effect & Overall Effect \\
\hline \multirow{4}{*}{$\mathrm{INT} \rightarrow \mathrm{SHA}$} & $\mathrm{INT} \rightarrow \mathrm{BSE} \rightarrow \mathrm{ACT} \rightarrow \mathrm{SHA}$ & 0.12077 & \multirow{4}{*}{0.20027} \\
\hline & $\mathrm{INT} \rightarrow \mathrm{DSE} \rightarrow \mathrm{ACT} \rightarrow \mathrm{SHA}$ & 0.04486 & \\
\hline & $\mathrm{INT} \rightarrow \mathrm{BSE} \rightarrow \mathrm{LEA} \rightarrow \mathrm{SHA}$ & 0.01837 & \\
\hline & $\mathrm{INT} \rightarrow \mathrm{DSE} \rightarrow \mathrm{LEA} \rightarrow \mathrm{SHA}$ & 0.00396 & \\
\hline \multirow{2}{*}{$\mathrm{BSE} \rightarrow \mathrm{SHA}$} & $\mathrm{BSE} \rightarrow \mathrm{ACT} \rightarrow \mathrm{SHA}$ & 0.23219 & \multirow{2}{*}{0.26744} \\
\hline & $\mathrm{BSE} \rightarrow \mathrm{LEA} \rightarrow \mathrm{SHA}$ & 0.03525 & \\
\hline \multirow{2}{*}{$\mathrm{DSE} \rightarrow \mathrm{SHA}$} & $\mathrm{DSE} \rightarrow \mathrm{ACT} \rightarrow \mathrm{SHA}$ & 0.23488 & \multirow{2}{*}{0.25561} \\
\hline & $\mathrm{DSE} \rightarrow \mathrm{LEA} \rightarrow \mathrm{SHA}$ & 0.02073 & \\
\hline \multirow{2}{*}{$\mathrm{ACT} \rightarrow \mathrm{SHA}$} & $\mathrm{ACT} \rightarrow \mathrm{SHA}$ & 0.673 & \multirow{2}{*}{0.723} \\
\hline & $\mathrm{ACT} \rightarrow \mathrm{LEA} \rightarrow \mathrm{SHA}$ & 0.050 & \\
\hline $\mathrm{LEA} \rightarrow \mathrm{SHA}$ & $\mathrm{LEA} \rightarrow \mathrm{SHA}$ & 0.141 & 0.141 \\
\hline
\end{tabular}

\section{Conclusions and Discussion}

The linear influence relationships (attention $\rightarrow$ interest $\rightarrow$ search $\rightarrow$ action $\rightarrow$ share) of the AISAS were significantly positive, while only some of the nonlinear influence relationships were significant and weaker than the linear ones. These results are consistent with those of Hendriyani et al. and Cheah et al., and also verify that the AISAS model is more suitable than AIDMA for explaining the behavioral characteristics of tourism consumers in the Internet era [56,76].

The findings on the influential factors on action were that only information search, both pre-travel and during travel, had a significant influence on action and the influence coefficient for information search pre-travel was larger than that of information search during travel. However, attention and interest had no direct effects on action. It was concluded that information search is crucial for action, which is consistent with previous studies and verified that online consumers actively seek marketing information. Xu, Hao, and Han argued that information search has become an important part of the behavior of Net Generation consumers who communicate easily with other people by taking advantage of the characteristics of Internet communities [67]. Sánchez, Williams, and García-Andreu suggested that communication strategies are essential to reduce risks and build trust [86]. However, information search in different stages has a varying influence on action. The effect of search during travel on action is a little greater than that of search before travel, which shows that many tourism consumption decisions are quickly made during trips. The reason can be attributed to the characteristics of the Net Generation who seek innovation, change, and customization. They prefer to travel freely, hoping to fully control the pace of their travel and plan their own itineraries [32].

Attention-affected action through information search and interest before and during travel, which had the greatest effect on action, was higher than the impact of information search before and during travel on action. Among the three paths of attention influencing action, the most important one was to induce action indirectly through interest. These results indicated that attention and interest are two very important factors that are needed to attract attention; however, they have no direct effect on action. This is consistent with previous research that stated that, since more people want to learn about products through content rather than advertising, the purpose of digital content marketing is to improve appreciation of companies or brands by increasing consumers' life value, and indirectly foster long-term cultivate sales by developing participation, trust, and relationships. In contrast, the purpose of traditional advertising is to persuade people to buy products $[87,88]$. Therefore, it is of great importance to draw attention to product and service information provided by online travel platforms, which arouse interest that will likely be followed by information search. If products or services meet expectations, purchase decisions are 
made, which then influence action [89]. This is also consistent with previous studies from other fields. Li \& Zhao (2019) proposed that due to the importance of attention, it is more effective to release the product message earlier [90]. However, these findings are different from Howard and Sheth's buying process stages. They proposed that the buying process begins with demand recognition, while this research found that the information from enterprises stimulates the generation of internal demand by attracting the attention of consumers and then arousing interest and information search. This difference may be a result of the development of Internet technology.

Second, this study also focused on sharing behavior after travel and introduced the variable of learning and growth, which was found to be influenced by action and information search (both pre-travel and during travel). This is because consumers can plan their own itineraries, experience local life flexibly and freely, understand local culture more deeply [80], satisfy their demand for autonomy and flexibility $[77,78,83]$, and achieve learning and growth by utilizing the information provided by various online channels [32]. Action and learning and growth were important factors affecting sharing behavior, while information search had no influence. This suggests that consumers will share their collected information, comments, and experiences only after they have first-hand experiences [84]. Previous research has revealed that travelers share post-travel life experiences and social interactions [91-93].

Third, post-travel sharing has a significant positive effect on attention. People sharing post-travel experiences with others leads to another round of attention, interest, search and action, affecting potential travelers' decisions to purchase tourism products [70]. When customers use products or services, they actively create user contents on open platforms like blogs, community websites, and forums. They post comments and support (or lack thereof) for products and services in various forms. People share shopping or other user experiences as a way to demonstrate personal experiences and what they share draws the attention of other potential buyers [94]. Post-travel sharing from eWoM is considered to have higher credibility than the information from companies. Therefore, post-travel sharing of information has a significant influence on new levels of attention $[95,96]$. Thus, it is critical for travel marketers to pay attention to post-travel sharing and to actively encourage tourists to share positive experiences.

The innovation in this work was that in addition to considering the whole process of information search behavior before, during and after travel, the intermediate variable of learning and growth was introduced. It also showed that information search not only serves as a tool for itinerary mapping and consumption decision-making, but also can satisfy tourists' knowledge needs. Therefore, tourism information platforms and related enterprises should pay attention to the provision of knowledge content.

\section{Implications and Limitations \\ 6.1. Theoretical Implications}

This research explored the online consumption behavior of Net Generation tourists based on the AISAS model with the introduction of the variable of learning and growth as a dependent variable. The findings revealed that the AISAS model is more suitable than AIDMA for explaining the behavioral characteristics of consumers in the Internet era. Net Generation consumers take actions after information search, both pre-travel and during travel, but do not do so only after attention and interest are evoked. They are more likely to take actions after information searches during travel than pre-travel. Attention influences action via three paths: information searches pre-travel, information search during travel, and interest. The most important path is to promote information search through interest, so as to indirectly influence action. Action and information search (both pre-travel and during travel) facilitate learning and growth. In turn, learning and growth and action promote sharing behavior after travel. Post-travel sharing stimulates attention and causes another cycle of AISAS. 


\subsection{Practical Implications}

AISAS provides online travel marketers with a model to better understand the underlying rationale of travelers' decisions. They need to carefully consider all stage linkages (i.e., attention-interest, interest-search (pre-travel, during travel), search-action, action-share; share-attention), and develop marketing initiatives and customer engagement accordingly. The share-attention linkage is especially important as it connects past with potential customers and is an opportunity for content co-creation.

The search behaviors and comment sharing about past travel experiences is key to accurately comprehending customer needs. It is essential to attract and engage with customers by creating and delivering what is needed, relevant, valuable, and consistent, and gives customers information about problems they want to solve. In addition, travel marketers must pay greater attention to the role of learning and growth. Besides the postings about experiences, people also actively share contents that expand their personal knowledge and stimulate self-growth. Therefore, in addition to basic travel information, content should be provided that helps to improve itinerary planning, and on how to engage more meaningfully with local cultural experiences. Above all, online platforms must provide personalized tourism products reflecting distinct destination characteristics. Marketers need to facilitate the learning and growth of travelers, especially from the Net Generation, through the sharing of professional and personalized knowledge. Thereafter, the sharing by travelers will be more knowledge-based and realistic. As a source of information for new potential customers, this sharing may be more persuasive than that provided by companies and destinations themselves. Online travel platforms should carefully select the products and services that provide customers with high-quality experiences. In this way, customers are more likely to share experiences after traveling and upload favorable comments, which is conducive to building potential customers' trust in the reliability of the information. Many network platforms provide customers with more choices of information search sites. Through improvements of systems, service, and design quality, search environments that customers like should be designed that improve experiences and encourage customers to use the platforms for one-stop information search and purchasing.

\subsection{Limitations and Future Research Directions}

The first limitation of this study is that it was only conducted with Net Generation participants in Taiwan. It did not take into accounts other age groups of research participants. Subsequent research should expand the scope and contrast the behaviors of different generations on online travel platforms. In addition, this study did not analyze the effects of different social media on consumer behavior with respect to online travel platforms. Future research should test for platform effects and differences. Due to the increasing popularity of mobile applications, future investigations should also include mobile apps and compare mobile apps and existing travel platforms. In addition, the research was completed before COVID-19 without considering the impact of the pandemic on tourist behavior. The tourism industry has been greatly affected by COVID-19, and the behavior of tourists has changed accordingly. It is suggested to further explore the behavior of tourists in the pandemic crisis, and compare with this study's findings to confirm changes in tourist behavior.

Author Contributions: Conceptualization, C.-C.S.; Data curation, L.-L.X.; Formal analysis, C.-C.S.; Investigation, L.-L.X.; Methodology, L.-W.K.; Project administration, L.-L.X.; Supervision, C.-C.S. Validation, L.-W.K.; Writing—original draft, L.-L.X., A.M.M.; Writing—review \& editing, C.-C.S. and A.M.M. All authors have read and agreed to the published version of the manuscript.

Funding: This study is sponsored by K.C. Wong Magna Fund in Ningbo University.

Institutional Review Board Statement: This study adopted anonymous questionnaire method and took $\mathrm{N}$ generation tourists as sample. All of the questions do not involve personal privacy, nor do they involve personal feelings issues. According to the policy requirements of our region, this kind of research is not required academic ethics approval. 
Informed Consent Statement: Informed consent was obtained from all subjects involved in the study.

Data Availability Statement: Not applicable.

Acknowledgments: We would like to express our sincere appreciation to the reviewers.

Conflicts of Interest: The authors declare no conflict of interest.

\section{References}

1. Amaro, S.; Duarte, P. Online travel purchasing: A literature review. J. Travel Tour. Mark. 2013, 30, 755-785. [CrossRef]

2. Buhalis, D.; Law, R. Progress in information technology and tourism management: 20 years on and 10 years after the Internet: The state of eTourism research. Tour. Manag. 2008, 29, 609-623. [CrossRef]

3. Law, R.; Buhalis, D.; Cobanoglu, C. Progress on information and communication technologies in hospitality and tourism. Eur. J. Mark. 2014, 26, 727-750. [CrossRef]

4. Pencarelli, T. The digital revolution in the travel and tourism industry. Inf. Technol. Tour. 2019, 22, 455-476. [CrossRef]

5. Xue, L.L.; Shen, C.C.; Lin, C.N.; Hsieh, K.L. Factors affecting the business model innovation employed by small and micro travel agencies in the Internet+ era. Sustainability 2019, 11, 5322. [CrossRef]

6. Taiwan Network Information Center. A Survey on Broadband Internet Usage in Taiwan in 2016. 2016. Available online: http: / / www.twnic.net.tw/download/200307/20160922e.pdf (accessed on 2 October 2018).

7. Assaker, G.; Hallak, R.; El-Haddad, R. Consumer usage of online travel reviews: Expanding the unified theory of acceptance and use of technology 2 model. J. Vacat. Mark. 2020, 26, 149-165. [CrossRef]

8. Fang, B.; Ye, Q.; Kucukusta, D.; Law, R. Analysis of the perceived value of online tourism reviews: Influence of readability and reviewer characteristics. Tour. Manag. 2016, 52, 498-506. [CrossRef]

9. Jimura, T.; Lee, T.J. The impact of photographs on the online marketing for tourism: The case of Japanese-style inns. J. Vacat. Mark. 2020, 26, 354-364. [CrossRef]

10. Litvin, S.W.; Goldsmith, R.E.; Pan, B. Electronic word-of-mouth in hospitality and tourism management. Tour. Manag. 2008, 29, 458-468. [CrossRef]

11. Magno, F.; Cassia, F.; Bruni, A. “Please write a (great) online review for my hotel!" Guests' reactions to solicited reviews. J. Vacat. Mark. 2018, 24, 148-158. [CrossRef]

12. San Martín, H.; Herrero, A. Influence of the user's psychological factors on the online purchase intention in rural tourism: Integrating innovativeness to the UTAUT framework. Tour. Manag. 2012, 33, 341-350. [CrossRef]

13. Wen, I. Factors affecting the online travel buying decision: A review. Int. J. Contemp. Hosp. Manag. 2009, 21, 752-765. [CrossRef]

14. Wen, I. An empirical study of an online travel purchase intention model. J. Travel Tour. Mark. 2012, 29, 18-39. [CrossRef]

15. Howard, J.A.; Sheth, J.N. The Theory of Buyer Behavior; John Wiley \& Sons: New York, NY, USA, 1969.

16. Engel, J.E.; Blackwell, R.D.; Kollat, D.T. Consumer Behavior, 7th ed.; Dryden Press: New York, NY, USA, 1993.

17. Morrison, A.M. Marketing and Managing Tourism Destinations, 2nd ed.; Routledge: London, UK, 2019.

18. Dimitriou, C.K.; AbouElgheit, E. Understanding generation z's social decision-making in travel. Tour. Hosp. Manag. 2019, 25, 311-334. [CrossRef]

19. Han, Y.; Zhang, T.; Wang, M. Holiday travel behavior analysis and empirical study with Integrated Travel Reservation Information usage. Transp. Res. Part A 2020, 134, 130-151. [CrossRef]

20. Osei, B.A.; Abenyin, A.N. Applying the Engell-Kollat-Blackwell model in understanding international tourists' use of social media for travel decision to Ghana. Inf. Technol. Tour. 2016, 16, 265-284. [CrossRef]

21. Woodside, A.G.; King, R.I. An updated model of travel and tourism purchase-consumption systems. J. Travel Tour. Mark. 2001, 10, 3-27. [CrossRef]

22. Choi, S.; Lehto, X.Y.; Morrison, A.M.; Jang, S. Structure of travel planning processes and information use patterns. J. Travel Res. 2012, 51, 26-40. [CrossRef]

23. Dentsu Inc. Digitization Changing the Consumer Purchasing Process: From AIDMA to AISAS. 2006. Available online: http: //www.dentsu.com/ir/marketing/pdf/AR2006_E6.pdf (accessed on 15 October 2018).

24. Team Tourism Consulting. A Practical Guide to Tourism Destination Management; UNWTO: Madrid, Spain, 2007.

25. Tsai, K. Tourism Cycle Map. 2016. Available online: https://blog.tiandiren.tw/archives/23146 (accessed on 2 October 2018).

26. Jang, S.S. The past, present, and future research of online information search. In Handbook of Consumer Behavior, Tourism, and the Internet; Routledge: London, UK, 2013; pp. 58-65.

27. Lee, M.K.; Yoon, H.Y.; Park, H.W. From online via offline to online: How online visibility of tourism information shapes and is shaped by offline visits. J. Travel Tour. Mark. 2017, 34, 1143-1154. [CrossRef]

28. Creevey, D.; Kidney, E.; Mehta, G. From dreaming to believing: A review of consumer engagement behaviours with brands' social media content across the holiday travel process. J. Travel Tour. Mark. 2019, 36, 679-691. [CrossRef]

29. Draper, J. An exploratory study of the differences in prior travel experience and tourist information sources. Tour. Hosp. Res. 2016, 16, 133-143. [CrossRef]

30. Tourism Bureau of the Ministry of Transportation and Communications. The Survey and Analysis of Taiwanese Tourism in 2016. 2019. Available online: https:/ / admin.taiwan.net.tw /Handlers /FileHandler.ashx?fid=5525f436-78fc-4f41-8ecd-f7f01588f318 \&type $=4 \&$ no $=1$ (accessed on 2 October 2020). 
31. Fotis, F.; Buhalis, D.; Rossides, N. Social media impact on holiday travel planning: The case of the Russian and the FSU markets. Int. J. Online Mark. 2011, 1. [CrossRef]

32. Chen, C.-M. A Study of Tourism Motivation, Post-Travel Satisfaction and Loyalty-A Case Study of Different Ways of Traveling Abroad. Master's Thesis, National Chiao Tung University, Hsinchu City, Taiwan, 2011. Unpublished.

33. Zhou, K.Z.; Brown, J.R.; Dev, C.S. Market orientation, competitive advantage, and performance: A demand-based perspective. J. Bus. Res. 2009, 62, 1063-1070. [CrossRef]

34. Ku, E.C.; Yang, C.M.; Huang, M.Y. Partner choice: Adaptation of strategic collaboration between travel agencies. J. Hosp. Tour. Res. 2013, 37, 516-536. [CrossRef]

35. Ade, L.P.K.; Akanbi, A.M.A.; Tubosun, A.I. The influence of marketing intelligence on business competitive advantage (A study of Diamond Bank Plc). J. Compet. 2017, 9, 51-71.

36. Tahmasebifard, $\mathrm{H}$. The role of competitive intelligence and its subtypes on achieving market performance. Cogent Bus. Manag. 2018, 5, 1540073. [CrossRef]

37. Ali, N.E.; Maryam, J. Studying impacts of sales promotion on consumer's psychographic variables. Interdiscip. J. Contemp. Res. Bus. 2012, 3, 1278-1288.

38. Ulanat, M.; Jacob, K.P. Facilitating brand promotion through online social media: A business case study. In Hybrid Intelligence for Social Networks; Banati, H., Bhattacharyya, S., Mani, A., Köppen, M., Eds.; Springer: Cham, Switzerland, 2017 ; pp. $207-225$.

39. Liu, F.; Xiao, B.; Lim, E.T.; Tan, C.W. The art of appeal in electronic commerce: Understanding the impact of product and website quality on online purchases. Internet Res. 2017, 27, 752-771. [CrossRef]

40. Mudambi, S.M.; Schuff, D. What makes a helpful online review? A study of customer reviews on Amazon.com. MIS Q. 2010, 34, 185-200. [CrossRef]

41. Zhang, H.; Zhao, L.; Gupta, S. The role of online product recommendations on customer decision making and loyalty in social shopping communities. Int. J. Inf. Manag. 2018, 38, 150-166. [CrossRef]

42. Lei, S.S.L.; Pratt, S.; Wang, D. Factors influencing customer engagement with branded content in the social network sites of integrated resorts. Asia Pac. J. Tour. Res. 2017, 22, 316-328. [CrossRef]

43. Repovienè, R.; Pažèraitè, A. Content marketing decisions for customers' desired value in the tourism sector. Res. Rural Dev. 2019, 2, 284-291.

44. Kotler, P. Marketing 4.0. Available online: https://www.bua.nl/media/22/9789462762022-marketing-4.0-inkijkex.pdf (accessed on 10 September 2018).

45. Binkhorst, E.; Den Dekker, T. Agenda for co-creation tourism experience research. J. Hosp. Mark. Manag. 2009, 18, 311-327. [CrossRef]

46. Grissemann, U.S.; Stokburger-Sauer, N.E. Customer co-creation of travel services: The role of company support and customer satisfaction with the co-creation performance. Tour. Manag. 2012, 33, 1483-1492. [CrossRef]

47. Cabiddu, F.; Lui, T.-W.; Piccoli, G. Managing value co-creation in the tourism industry. Ann. Tour. Res. 2013, 42, 86-107. [CrossRef]

48. Bennett, S.; Maton, K.; Kervin, L. The 'digital natives' debate: A critical review of the evidence. Br. J. Educ. Technol. 2008, 39, 775-786. [CrossRef]

49. Leung, L. Generational differences in content generation in social media: The roles of the gratifications sought and of narcissism. Comput. Hum. Behav. 2013, 29, 997-1006. [CrossRef]

50. Hargittai, E. Digital na(t)ives? Variation in Internet skills and uses among members of the "Net Generation". Sociol. Inq. 2010, 80, 92-113. [CrossRef]

51. Jones, C.; Ramanau, R.; Cross, S.; Healing, G. Net generation or digital natives: Is there a distinct new generation entering university? Comput. Educ. 2010, 54, 722-732. [CrossRef]

52. Barry, T.E.; Howard, D.J. A review and critique of the hierarchy of effects in advertising. Int. J. Advert. 1990, 9, 121-135. [CrossRef]

53. Wijaya, B.S. The development of hierarchy of effects model in advertising. Int. Res. J. Bus. Stud. 2012, 5, 73-85. [CrossRef]

54. Hassan, S.; Nadzim, S.Z.A.; Shiratuddin, N. Strategic use of social media for small business based on the AIDA model. Procedia Soc. Behav. Sci. 2015, 172, 262-269. [CrossRef]

55. Hall, S.R. The Handbook of Sales Management: A Review of Modern Sales Practice and Management; McGraw-Hill Book Company: New York, NY, USA, 1924.

56. Hendriyani, J.J.; Ceng, L.; Utami, N.; Priskila, R.; Anggita, S. Online consumer behavior: Confirming the AISAS model on Twitter users. In Proceedings of the International Conference on Social and Political Sciences, Karawaci, Indonesia, 25-26 February 2013.

57. Hu, Z.; Qiao, J. Research on We Chat matrix marketing process of e-commerce enterprises based on AISAS model. In Proceedings of the 2017 International Conference on Arts and Design, Education and Social Sciences 2017, Yinchuan, China, 9 December 2017; pp. 878-884. [CrossRef]

58. Miao, L.; Kim, J.W. Research of animation movie marketing strategy in AISAS model: A case study of "Zootopia". TECHART J. Arts Imaging Sci. 2017, 4, 28-30. [CrossRef]

59. Pelawi, Y.N.; Aprilia, M.P. Implementation of marketing communication strategy in attention, interest, search, action, and share (AISAS) model through vlog. In Proceedings of the 2019 IEEE 4th International Conference on Computer and Communication Systems (ICCCS), Singapore, 23-25 February 2019; pp. 604-607.

60. Rini, M. The influence of endorser in social media toward consumer decision making with AISAS model (Attention, Interest, Search, Action, and Share). ECSOFiM Econ. Soc. Fish. Mar. 2018, 6, 106-118. [CrossRef] 
61. Zhao, Z.; Zhu, J.; Yang, Y.; Li, P.; Gu, J.; He, X. Research on the optimizing tourism market position of Xiaonanhai National Geopark based on AISAS consumer behavior analysis model. In International Academic Conference on Frontiers in Social Sciences and Management Innovation (IAFSM 2018); Atlantis Press: Paris, France, 2019.

62. Abdurrahim, M.S.; Najib, M.; Djohar, S. Development of AISAS model to see the effect of tourism destination in social media. J. Apl. Manaj. 2019, 17, 133-143. [CrossRef]

63. Kuang, J.Q. An application study of the AISAS model-based hotel e-marketing. Appl. Mech. Mater. 2013, 241, 3224-3228. [CrossRef]

64. Chen, Y.L.; Huang, T.Z. Mechanism research of OWOM marketing based on SOR and AISAS. Adv. Mater. Res. 2012, 403, 3329-3333. [CrossRef]

65. Liu, W.-L. Internet Marketing: 3A Era Is Coming; Gotop Information Inc.: Taipei, China, 2014.

66. Ai, C. Advertising; Yuan Huawen Chuang Press: Taipei, Taiwan, 2015.

67. Xu, C.; Hao, Q.; Han, G. Research on the marketing strategy of the new media age based on AISAS model: A case study of micro channel marketing. In Proceedings of the Fourth International Forum on Decision Sciences. Uncertainty and Operations Research; Li, X., Xu, X., Eds.; Springer: Singapore, 2017; pp. 477-486.

68. Kuo, C. Change of shopping behavior in Taiwanese consumers: Examining the AISAS model of online consumer behavior. Chin. J. Commun. Res. 2015, 27, 139-165.

69. Filieri, R.; McLeay, F. E-WOM and accommodation: An analysis of the factors that influence travelers' adoption of information from online reviews. J. Travel Res. 2014, 53, 44-57. [CrossRef]

70. Kono, S. From the marketers' perspective: The interactive media situation in Japan. In Television Goes Digital; Gerbarg, D., Ed.; Springer: New York, NY, USA, 2009; Volume 1, pp. 57-59.

71. Tao, Y.; Pei, G.Y. Analysis of Internet marketing based on the AISAS theory. Mark. Mod. 2007, 9, 211-212.

72. Shim, S.; Eastlick, M.A.; Lotz, S.L.; Warrington, P. An online pre-purchase intentions model: The role of intention to search J. Retail. 2001, 77, 397-416. [CrossRef]

73. Jun, S.H.; Vogt, C.A.; MacKay, K.J. Relationships between travel information search and travel product purchase in pre-trip contexts. J. Travel Res. 2007, 45, 266-274. [CrossRef]

74. Lee, H.Y.; Qu, H.L.; Kim, Y. A study of the impact of personal innovativeness on online travel shopping behavior-A case study of Korean travelers. Tour. Manag. 2007, 28, 886-897. [CrossRef]

75. Lin, H.F.; Chen, C.H. The persuasion effect of sociability in the design and use of an augmented reality wedding invitation app. J. Internet Technol. 2010, 20, 269-282.

76. Cheah, J.H.; Ting, H.; Cham, T.H.; Memon, M.A. The effect of selfie promotion and celebrity endorsed advertisement on decision-making processes: A model comparison. Internet Res. 2019, 29, 552-577. [CrossRef]

77. Hyde, K.F.; Lawson, R. The nature of independent travel. J. Travel Res. 2003, 42, 13-23. [CrossRef]

78. Tsaur, S.-H.; Yen, C.-H.; Chen, C.-L. Independent tourist knowledge and skills. Ann. Tour. Res. 2010, 37, 1035-1054. [CrossRef]

79. Ateljevic, I.; Doorne, S. Theoretical Encounters: A Review of Backpacker Literature; Channel View Publications: Clevedon, UK, 2004.

80. Muzaini, H. Backpacking Southeast Asia: Strategies of "looking local". Ann. Tour. Res. 2006, 33, 144-161. [CrossRef]

81. Loker-Murphy, L. Backpackers in Australia: A motivation-based segmentation study. J. Travel Tour. Mark. 1996, 5, 23-45. [CrossRef]

82. Elsrud, T. Risk creation in traveling: Backpacker adventure narration. Ann. Tour. Res. 2001, 28, 597-617. [CrossRef]

83. Hsu, C.Y.; Lee, W.H.; Chen, W.Y. How to catch their attention? Taiwanese flashpackers inferring their travel motivation from personal development and travel experience. Asia Pac. J. Tour. Res. 2017, 22, 117-130. [CrossRef]

84. Loker-Murphy, L.; Pearce, P.L. Young budget travelers: Backpackers in Australia. Ann. Tour. Res. 1995, 22, 819-843. [CrossRef]

85. Murphy, L. Exploring social interactions of backpackers. Ann. Tour. Res. 2001, 28, 50-67. [CrossRef]

86. Sánchez, I.R.; Williams, A.; García-Andreu, H. Customer resistance to tourism innovations: Entrepreneurs' understanding and management strategies. J. Travel Res. 2019, 59, 450-464. [CrossRef]

87. Hollebeek, L.D.; Macky, K. Digital content marketing's role in fostering consumer engagement, trust, and value: Framework, fundamental propositions, and implications. J. Interact. Mark. 2019, 45, 27-41. [CrossRef]

88. Jarvinen, J.; Taiminen, H. Harnessing marketing automation for B2B content marketing. Ind. Mark. Manag. 2016, 54, 164-175. [CrossRef]

89. Sugiyama, K.; Andree, T. The Dentsu Way: Secrets of Cross Switch Marketing from the World's Most Innovative Advertising Agency; McGraw Hill Professional: New York, NY, USA, 2010.

90. Li, H.; Zhao, N. Better Earlier than Longer: First-Mover Advantage in Social Commerce Product Information Competition. Sustainability 2019, 11, 4630. [CrossRef]

91. Pan, B.; MacLaurin, T.; Crotts, J.C. Travel blogs and the implications for destination marketing. J. Travel Res. 2007, 46, 35-45. [CrossRef]

92. Ramos-Soler, I.; Martínez-Sala, A.M.; Campillo-Alhama, C. ICT and the sustainability of World Heritage Sites. Analysis of senior citizens' use of tourism Apps. Sustainability 2019, 11, 3203. [CrossRef]

93. Lee, P.; Hunter, W.C.; Chung, N. Smart tourism city: Developments and transformations. Sustainability 2020, 12, 3958. [CrossRef]

94. Akehurst, G. User generated content: The use of blogs for tourism organisations and tourism consumers. Serv. Bus. 2009, 3, 51. [CrossRef] 
95. Xie, K.L.; Chen, C.; Wu, S. Online consumer review factors affecting offline hotel popularity: Evidence from TripAdvisor. J. Travel Tour. Mark. 2016, 33, 211-223. [CrossRef]

96. Kim, M.J.; Chung, N.; Lee, C.K.; Preis, M.W. Motivations and use context in mobile tourism shopping: Applying contingency and task-technology fit theories. Int. J. Tour. Res. 2015, 17, 13-24. [CrossRef] 